\title{
PERANAN HUKUM DALAM PENGEMBANGAN INDUSTRI PERTAHANAN SEBAGAI INDUSTRI STRATEGIS DIDALAM MENJAGA KEDAULATAN NEGARA KESATUAN REPUBLIK INDONESIA
}

\author{
Rahmanisa Purnamasari Faujura \\ Universitas Wiralodra \\ Email : rahmanisaa@gmail.com
}

\begin{abstract}
Indonesia's geographical located between two continents and oceans, those are the Asian nd the Australian Continent, and the Indian and the Pacific Ocean, has made Indonesia to become a country with strategic position, both for the world trade route and inter-State relations. But on the other hand Indonesia has the sovereignty of the State that must be guarded and maintained from all kinds of threats both from within and outside. For this reason, Indonesia is required to have the capacity in the form of TNI defense equipment, which is adequate as the main instrument to protect territorial sovereignty and to safeguard national interests from the threats, challenges, obstacles and disturbances both from domestic and foreign. Therefore, the development of the defense industry is also needed. The main problem in this study is how does the law regulate the development of defense industry as Indonesia's strategic industry?The descriptive method of analysis with normative juridical was used in analyzing the problems of the development of the defense industry in facing the challenges, threats, and disruptions to the Republic of Indonesia's sovereignty as a consequence of the strategic location of Indonesia's geographical position.

The results of the study show that the defense industry has a position as a strategic industry, because the primary weaponry defense system has important role in order to maintain the sovereignty of the State. Even though the regulation has been assigned in a law, namely Law Number 16 of 2012 concerning on the Defense Industry, but it has not been regulated by clear regulations and is tend to ad hoc, which is certainly not beneficial for the growth and development of the National defense industry. Law as a medium of renewing society must be able to make changes, so that it can direct where the national defense industry will be developed, so it is able to create companies that are reliable in producing defense equipment to preserve national sovereignty.
\end{abstract}

Keywords: defense, industry, regulation.

\section{PENDAHULUAN}

Indonesia merupakan negara yang berada pada posisi sangat strategis dalam lingkup kawasan Asia Tenggara. Nilai strategis Indonesia tersebut dapat dilihat dari segi selain karena Indonesia dianggap sebagai negara yang berdaulat saja, melainkan disebabkan pula oleh letak geografisnya yang berada diantara dua benua Benua Asia serta Benua Australia dan diantara dua samudra Samudra Hindia beserta Samudra Pasifik sehingga dalam hal ini menjadikan Indonesia juga sebagai salah satu jalur strategis 
perdagangan dunia ${ }^{94}$.

Seiring dengan berkembanganya hubungan antar negara yang yang dilakukan oleh Indonesia dan timbulnya dinamika hubungan antar negara dalam mengamankan kepentingan nasional yang tidak jarang berbenturan dengan kepentingan nasional negara lain, hal ini menjadi salah satu penyebab terjadinya sengketa atau ketegangan antar negara yang terkadang dapat diselesaikan secara damai melalui jalur diplomatik maupun dengan jalur militer. Sebagai negara yang berdaulat tentunya negara Indonesia dituntut untuk memiliki kekuatan berupa alutsista TNI yang memadai sebagai instrumen utama menjaga menjaga kedaulatan teritorial serta mengamankan kepentingan nasional dari ancaman, tantangan, hambatan dan gangguan baik yang berasal dari dalam negeri maupun dari luar negeri.

Kegiatan pengembangan dan pemanfaatan alutsista TNI di Indonesia pun dapat dijadikan salah satu faktor penunjang yang dapat memberikan detterence effect ${ }^{95}$ (efek penggentar) kepada negara-negara lain, yang selalu memandang negara Indonesia secara sebelah mata karena ketergantungannya terhadap senjata dari negara lain. Maka dari itu tanpa adanya usaha mengurangi ketergantungan pasokan alutsista TNI dari negara lain kebesaran dan harga diri bangsa Indonesia dihadapan bangsa-bangsa lain khususnya di kawasan akan mudah diremehkan dan dipandang sebelah mata dalam berunding melaui jalur diplomatik maupun konfrontasi terbuka melalui operasi militer.

Sejalan dengan permasalahan tersebut, hal ini merupakan dampak dari terabaikannya pembangunan industri pertahanan indonesia yang merupakan salah satu dari industri strategis di Indonesia, industri pertahanan indonesia yang seharusnya dapat menjadi salah satu kegiatan yang membantu pembangunan nasional dalam mewujudkan tujuan negara yang tertulis dalam Pembukaan Undang- Undang Dasar Republik Indonesia Tahun 1945, pada kenyataannya berada dalam kondisi tidak baik dan bermasalah baik dari segi finansial maupun pengaturan dalam pengelolaan sehingga akhirnya tidak cukup kompetitif dibanding industri pertahanan dari negara lain. Kurangnya keberadaan peraturan perundang - undangan yang seharusnya berperan sebagai hukum yang mengatur dan mengarahkan jalan perkembangan industri pertahanan Indonesia sebagai industri strategis Indonesia ini menjadikan perkembangan industri pertahanan Indonesia yang

${ }^{94}$ Wiranto Arismunandar, Strategi Pengembangan Teknologi dan Industri Pertahanan dalam rangka Mewujudkan Kemandirian Pertahanan Nasional, Jakarta; PT. Erlangga, 2000, hlm. 12.

95 Martin, The Economic of Offset: Defence Procurement and Countertrade (Terjemahan); Amsterdam; Routledge, 2007, hlm. 87. 
dapat membantu pembangunan nasional tidak dapat dilakukan oleh Indonesia.

Maka dari itu jika dilihat dari permasalahan tersebut tentunya tujuan hukum yang memberikan suatu ketertiban dan keadilan tidaklah tercapai dalam mewujudkan suatu pembangunan nasional yang dicita - citakan oleh Indonesia,yang seharusnya dapat dilakukan melalui perngembangan industri pertahanan Indonesia sebagai Industri Strategis Indonesia yang dapat menghasilkan sedikitnya suatu perkembangan baik dalam segi ekonomi maupun dalam mempertahankan kedaulatan negara. Dengan demikian bagaimanakah peranan hukum dalam pengembangan dan pemanfaatan industri pertahanan sebagai industri strategis di Indonesia?

\section{METODE DAN PENEDAKATAN}

Spesifikasi penelitian ini adalah deskriptif analitis, dengan pendekatan Yuridis Normatif, yaitu penelitian yang bertujuan menggambarkan mengenai fakta-fakta disertai analisis yang akurat mengenai peraturan perundang-undangan penelitian yang menitikberatkan pembahasan pada data-data sekunder berupa bahan-bahan hukum, baik primer, sekunder maupun tersier, yang didukung data primer.

Teknik pengumpulan data dilakukan melalui Penelitian kepustakaan yakni untuk memperoleh bahan-bahan hukum baik primer, sekunder, maupun tersier. ${ }^{96}$ Bahan hukum primer adalah bahan-bahan yang berasal dari peraturan perundang-undangan, antara lain UUD 1945, Undang - Undang Nomor 16 Tahun 2012 tentang Industri Pertahanan, Undang Undang Nomor 3 Tahun 2016 tentang Perindustrian Undang - Undang Nomor 3 Tahun 2016 tentang Perindustrian. Bahan-bahan hukum sekunder berkaitan dengan bahan-bahan hukum yang menjelaskan peraturan perundang-undangan, yakni RUU Industri Pertahanan, Doktrin, dan lain-lain. Sedangkan bahan hukum tersier berupa tulisan-tulisan dari jurnal, majalah, media social, dan lain-lain.

Teknis Analisis data yang digunakan dalam penelitian ini adalah deskriptif analisis normatif, yakni pemaparan dan penggambaran peraturan perundang-undangan secara kualitatif terhadap perlindungan industri pertahanan.

\section{PEMBAHASAN}

\subsection{Industri Pertahanan Sebagai Bagian Dari Industri Strategis Indonesia}

\footnotetext{
96 Sunaryati Hartono, Penelitian Hukum di Indonesia Pada Akhir Abad ke-20, Alumni, Bandung, 1994, hlm. 134
} 
Industri pertahanan merupakan salah satu sektor industri strategis di Indonesia yang memiliki ciri utama yaitu keberadaan teknologi tinggi serta inovasi yang melekat pada setiap tahapan proses produknya. Keberadaan Industri pertahanan dalam hal ini tidak hanya bermanfaat dalam rangka menjaga kedaulatan negara dalam segi militer, melainkan keberadaan industri pertahanan di Indonesia sebagai salah satu industri strategis menjadikan salah satu kegiatan yang mendukung pembangunan nasional di Indonesia ${ }^{97}$.

Industri Pertahanan yang lahir pada masa Orde Baru yaitu mulai muncul dengan keberadaan PT. Pindad pada tahun 1998 yang bergerak dalam bidang persenjataan yang dijadikan Alat Utama Sistem Pertahanan (alustsista). Keberadaan industri pertahanan tersebut tidak juga membuat Indonesia untuk mengesahkan suatu peraturan perundang undangan yang mengatur mengenai berjalannnya industri pertahanan. Keberadaan PT. Pindad sendiri berada dibawah pembinaan Badan Pengelola Industri Strategis (BPIS), namun,tahun 1998 BPIS dibubarkan sehingga seluruh perseroan yang berada di bawah pembinaannya menjadi anak perusahaan PT. Pakarya Industri (Persero). Tahun 1999 PT. Pakarya Industri (Persero) berubah nama menjadi PT. Bahana Pakarya Industri Strategis (Persero), yang kemudian dibubarkan melalui Peraturan Pemerintah Republik Indonesia Nomor 52 tahun 2002 Tentang Penyertaan Modal Negara Republik Indonesia ke Dalam PT DIRGANTARA INDONESIA, PT PAL INDONESIA, PT PINDAD, PT DAHANA, PT KRAKATAU STEEL, PT BARATA INDONESIA, PT BOMA BISMA INDRA, PT INDUSTRI KERETA API, PT INDUSTRI TELEKOMUNIKASI INDONESIA DAN PT LEN INDUSTRI DAN PEMBUBARAN PERUSAHAAN PERSEROAN (PERSERO) PT BAHANA PAKARYA INDUSTRI STRATEGIS.

Industri Pertahanan di Indonesia kemudian lahir kembali dengan keluarnya Peraturan Pemerintah Nomor 41 tahun 2003 Tentang Pelimpahan Kedudukan, Tugas dan Kewenangan Menteri Keuangan Pada Perusahaan Perseroan (PERSERO), Perusahaan Umum (PERUM), dan Perusahaan Jawatan (PERJAN) Kepada Menteri Negara Badan Usaha Milik Negara, yang mengartikan juga bahwa PT. Pindad (Persero) berada di bawah kewenangan Menteri Negara Badan Usaha Milik Negara.

Dari sejarah lahirnya industri pertahahan di Indonesia sendiri Indonesia baru mengesahkan peraturan perundang - undangan mengenai industri pertahanan pada tahun 2012 yaitu dengan lahirnya Undang - Undang Nomor 16 Tahun 2012 tentang Industri

97 Habibi Yusuf Sarjono , Peran Strategis Pembangunan Industri Pertahanan, Bandung, PT. Mandar Maju, 2011, hlm. 5 
Pertahanan, hal ini mengartikan bahwa selama Industri Pertahanan Indonesia berdiri memang sama sekali tidak diatur bagaimana industri tersebut dapat berjalan sesuai dengan tujuannya yaitu sebagai suatu Senjata Utama Sistem Pertahanan yang dapat membantu Indonesia dalam rangka pembangunan nasional yaitu mewujudkan cita - cita bangs yang tercantum dalam Pembukaan Undang - Undang Dasar Tahun 1945. Dengan baru disahkan peraturan perundang - undangan yang merupakan aturan dalam berjalannnya Industri pertahanan, mengartikan bahwa peranan hukum selama ini memang sangat kurang terhadap berjalannya industri pertahanan di Indonesia sehingga tidak menutup kemungkinan bahwa dampak yang terjadi adalah munculnya beberapa kendala spesifik terkait dengan pengelolaan industri strategis bidang pertahanan seperti ${ }^{98}$

a. In-efesiensi pengelolaan.

b. Mis-manajemen dalam pengelolaan.

c. Minimnya daya beli TNI sebagai end user untuk menyerap berbagai produksi industri strategis.

d. Kurangnya perhatian, pemanfaatan dan sinkronisasi lembaga penelitian pemerintah, perguruan tinggi maupun swasta dalam inovasi teknologi pertahanan dan keamanan yang memiliki daya saing.

e. Bahan baku baja yang masih bergantung pada produk impor yang mahal dan kurang terdukung produksi baja nasional.

\subsection{Peranan Hukum Dalam Industri Pertahanan Sebagai Salah Satu Industri Starategis Di Indonesia}

Pertahanan negara adalah upaya untuk menegakkan kedaulatan negara, mempertahankan keutuhan wilayah Negara Kesatuan Republik Indonesia (NKRI), dan keselamatan segenap bangsa dari ancaman militer serta ancaman bersenjata terhadap keutuhan bangsa dan negara ${ }^{99}$. Dalam hal ini keberadaan industri pertahanan seperti produk senjata menjadikan suatu hal yang penting dan menyangkut hajat hidup orang banyak dalam mempertahankan serta memberikan keamanan, sehingga dalam hal ini industri pertahanan dapat dikatakan menjadi suatu industri strategis yang mempengaruhi pula pembangunan nasional di Indonesia.

Pengertian dari industri strategis sendiri telah dijelaskan dalam Pasal 1 angka 4

\footnotetext{
98 Kementerian Pertahanan RI, Minimum Essensial Force, Jakarta; Komponen Utama Kemenpan RI, 2010, hlm. 16.

99 Juanda,Politik Internasional: Suatu Kerangka Analisis, Bandung; Bima Cipta, 1997, hlm. 117.
} 
Undang - Undang Nomor 3 Tahun 2016 tentang Perindustrian yang menjelaskan bahwa :

"Industri strategis adalah Industri yang penting bagi negara dan yang menguasai hajat hidup orang banyak, meningkatkan atau menghasilkan nilai tambahsumber daya alam strategis, atau mempunyai kaitan dengan kepentingan pertahanan serta keamanan negara dalam rangka pemenuhan tugas negara."

Diliat dari pengertiannya tentunya hal ini sejalan dengan landasan konstitusional dari adanya industri pertahanan yang berada pada pembukaan Undang - Undang Dasar Negara Republik Indonesia Tahun 1945 yang berbunyi :

"bahwa untuk melindungi segenap bangsa Indonesia dan seluruh tumpah darah Indonesia, serta untuk mempertahankan kedaulatan negara dan keutuhan wilayah Negara Kesatuan Republik Indonesia, pertahanan dan keamanan negara dilaksanakan melalui sistem pertahanan dan keamanan negara yang membutuhkan ketersediaan alat peralatan pertahanan dan keamanan serta didukung oleh kemampuan industri pertahanan dalam negeri yang mandiri untuk mencapai tujuan nasional;"

Industri Pertahanan sendiri memiliki kharakteristik khusus dalam bidang perindustrian, dimana bidang usaha pertahanan merupakan salah satu bidang usaha industri tertutup dari penanaman modal asing yang hal ini telah dijelaskan juga dalam Pasal 12 angka 2 Undang - Undang Nomor 25 Tahun 2007 tentang Penanaman Modal bahwa :

" Bidang usaha yang tertutup bagi penanam modal asing adalah:

a. produksi senjata, mesiu, alat peledak, dan peralatan perang; dan

b. bidang usaha yang secara eksplisit dinyatakan tertutup berdasarkan undang-undang"

Keberadaan industri pertahanan Indonesia sebagai bagian dari industri strategis Indonesia seharusnya dapat membuat Indonesia mudah dalam melakukan suatu kegiatan yang dapat berdampak pada pembangunan nasional di Indonesia, namun pada kenyataannya komponen pendukung, seperti industri pertahanan nasional, juga belum sepenuhnya dapat bersinergi dengan komponen inti sehingga kemampuan pertahanan negara belum dapat dibangun secara optimal. Di sisi lain ${ }^{100}$, secara geopolitik dan geostrategi, Indonesia terletak pada posisi yang strategis dan menentukan dalam tata pergaulan dunia dan kawasan, namun disisi lain peran hukum sebagai pengarah dalam berjalannya industri pertahanan masih belum mencapai tujuannya yaitu memberikan suatu

\footnotetext{
100 Margono, Kebijakan Modernisasi Alutsista Tni Dihadapkan Pada Tuntutan Tugas, Bandung; Yudhagama, 2012, hlm. 14.
} 
ketertiban dan keadilan.

Peraturan perundangan - undangan sebagai pengaturan pelaksanaan dari berjalannya industri pertahanan Indonesia tersebut sama sekali belum ada yang mengatur secara jelas dimulai sejak berdirinya industri pertahanan pertama di Indonesia yang lahir pada masa Orde Baru hingga pada tahun 2012 baru disahkannya Undang - Undang Nomor 16 Tahun 2012 tentang Industri Pertahanan. Keberadaan payung hukum nasional untuk memfasilitasi revitalisasi industri strategis nasional bidang pertahanan secara lebih terkonsentrasi, selama ini masih bersifat ad hoc dan parsial. Artinya, belum ada satu undang-undang yang mengatur secara tegas mengenai posisi industri pertahanan sebagai industri strategis nasional dalam pertahanan dan perekonomian nasional, adanya rancangan undang - undang untuk revitasilasi industri pertahanan sampai sekarang masih juga belum disahkan. Padahal didalam Rancangan Pembangunan Jangka Menengah Nasional Tahun 2015-2019 telah ditetapkan sasaran dan arah kebijakan dan startegi pengembangan industri pertahanan nasional.

Dalam hal ini peran hukum jelas dapat dikatakan kurang membantu dalam berjalannya perkembangan indusri pertahanan Indonesia sebagai bagian dari industri strategis Indonesia yang dapat mebantu pembangunan nasional di Indonesia.Sejalan dengan permasalahan tersebut, hukum yang seharusnya sebagai sarana pembaharuan sebagaimana yang dikemukakan oleh Mochtar Kusumaatmadja, ${ }^{101}$ dalam hal pengembangan industri pertahanan ini justru sama sekali tidak menjalankan hal tersebut sesuai dengan tujuannya yaitu menciptakan suatu ketertiban dan keadilan dalam melakukan suatu perkembangan atau pembangunan.

Mochtar Kusumaatmadja ${ }^{102}$ menjelaskan juga bahwa hukum sebagai sarana pembaharuan memiliki arti sebagai penyalur arah kegiatan manusia yang dikehendaki, yang dalam hal ini di dasari pada suatu anggapan bahwa adanya keteraturan dan ketertiban dalam usaha pembangunan merupakan suatu hal yang mutlak jika ingin mencapai pada pembangunan tersebut. Adapun maksud dari penjelasan Mochtar Kusumaatmadja tersebut mengartikan betapa pentingnya keberadaan hukum dalam melakukan suatu pembangunan khususnya yang menyangkut dengan pembangunan nasional di Indonesia, hukum akan membrikan suatu kepastian hukum yang menciptakan ketertiban dan keadilan dalam

101 Mochtar Kusumaatmadja, Konsep-Konsep Hukum Dalam Pembangunan (Kumpulan Karya Tulis), Bandung; Penerbit Alumni, 2002, hlm. 14

${ }^{102}$ Lili Rasjidi dan Ida Bagus Wiyasa Putra, Hukum Sebagai Suatu Sistem, Bandung; Penerbit: CV. Mandar Maju, 2003, hlm. 5 
pembangunan tersebut.

Tidak adanya pengaturan dalam pengelolaan industri pertahanan ini menjadikan juga industri swasta nasional yang mampu menghasilkan peralatan militer belum mendapat peran yang optimal dalam membantu berjalannya perusahaan industri pertahanan BUMN untuk menciptakan alutsista sendiri, begitu juga dengan konsep tiga pilar pelaku industri pertahanan sebagai lembaga dan proses yang tidak berjalan karena tidak ada pengaturannya yang jelas. Konsep tiga pilar pelaku industri pertahanan mengacu pada hubungan lembaga yang terpadu antara ${ }^{103}$

1. Perguruan Tinggi dan komunitas Penelitian dan Pengembangan (Litbang) sebagai pengembang Ilmu Pengetahuan dan Teknologi (Iptek) pertahanan

2. sektor industri/swasta sebagai pendaya guna hasil Iptek pertahanan, produksi maupun distribusinya, serta

3. TNI sebagai pengguna.

Perlu diingat juga bahwa dalam pembangunan dibutuhkan juga peran lembaga dan proses untuk mencapai tujuan yang diinginkan.

Maka dari itu dari penjelesan tersebut mengartikan bahwa dalam perkembangan industri pertahanan sebagai industri strategis Indonesia masih belum mendapatkan suatu kepastian hukum dalam rangka menuju pembangunan nasional, hukum dalam masalah ini tidak memberikan suatu kepastian hukum yang jelas dalam pembangunan industri pertahanan ini, sejalan dengan hal tersebut mengartikan bahwa hukum tidak akan mencapai suatu ketertiban dan juga keadilan.

\subsection{Arah Pengaturan Industri Pertahanan Sebagai Industri Strategis Di Indonesia}

Industri pertahanan adalah industri nasional, baik milik pemerintah maupun swasta yang produknya baik secara mandiri maupun kelompok, termasuk jasa perawatannya dapat dimanfaatkan untuk kepentingan pertahanan kedaulatan negara. Industri pertahanan ini merupakan jawaban dari tantangan keperluan pencapaian Minimum Essential Force $(M E F)^{104}$ di lingkungan TNI yang telah direncanakan juga dalam Rencana Pembangunan Jangka Menengah Nasional (RPMN) yang dimiliki oleh Indonesia. Industri pertahanan diatur dalam Undang - Undang Nomor 16 Tahun 2012 tentang Industri Pertahanan yang

103 Departemen Pertahanan Republik Indonesia, Buku Putih Pertahanan Indonesia, Jakarta; Departemen Pertahanan, 2008, hlm.3.

104 Sily Karim, Membangun Kemandirian Industri Pertahanan Indonesia, Jakarta; KPG, 2014, hlm. 21 
menjalaskan dalam Pasal langka 1 bahwa :

"Industri Pertahanan adalah industri nasional yang terdiri atas badan usaha milik negara dan badan usaha milik swasta baik secara sendiri maupun berkelompok yang ditetapkan oleh pemerintah untuk sebagian atau seluruhnya menghasilkan alat peralatan pertahanan dan keamanan, jasa pemeliharaan untuk memenuhi kepentingan strategis di bidang pertahanan dan keamanan yang berlokasi di wilayah Negara Kesatuan Republik Indonesia.

Suatu negara yang memiliki industri pertahanan dianggap mempunyai keuntungan strategis dalam tatanan global dikarenakan dianggap mampu melakukan penangkalan dan menjawab tantangan atau ancaman yang senantiasa berubah ${ }^{105}$.

Industri pertahanan yang pengertiannya menyangkut hajat hidup orang banyak, hal tersebut menjadikan industri pertahanan merupakan bagian dari industri strategis di Indonesia yang dapat membantu berjalannya pembangunan nasional di Indonesia, hal ini dipertegas dengan pengertian industri strategis yang dijelaskan dalam Pasal 1 angka 4 Undang - Undang Nomor 3 Tahun 2016 tentang Perindustrian, dijelaskan bahwa :

"Industri strategis adalah Industri yang penting bagi negara dan yang menguasai hajat hidup orang banyak, meningkatkan atau menghasilkan nilai tambahsumber daya alam strategis, atau mempunyai kaitan dengan kepentingan pertahanan serta keamanan negara dalam rangka pemenuhan tugas negara."

Upaya perwujudan industri pertahanan tidak terlepas juga dari konsep tiga pilar pelaku industri pertahanan dan konsep kluster industri pertahanan. Konsep tiga pilar pelaku industri pertahanan mengacu pada hubungan yang terpadu antara ${ }^{106}$

1. Perguruan Tinggi dan komunitas Penelitian dan Pengembangan (Litbang) sebagai pengembang Ilmu Pengetahuan dan Teknologi (Iptek) pertahanan

2. sektor industri/swasta sebagai pendaya guna hasil Iptek pertahanan, produksi maupun distribusinya, serta

3. TNI sebagai pengguna.

Sedangkan konsep kluster Industri pertahanan artinya adalah adanya saling keterkaitan dan saling mendukung antara industri hulu, industri hilir, industri pendukung dan industri terkait untuk menciptakan daya saing dan meningkatkan industri nasional ${ }^{107}$.

Adapun dalam hal ini, berikut beberapa Badan Usaha Milik Negara yang

105 Idem, hlm. 23

106 Departemen Pertahanan Republik Indonesia, Buku Putih Pertahanan Indonesia, Jakarta; Departemen Pertahanan, 2008, hlm.3.

107 Ibid. 
merupakan bagian dari Industri Pertahanan :

1. Perusahaan Perseroan (Persero) PT Dahana yang didirikan berdasarkan Peraturan Pemerintah Nomor 17 tahun 1991 berkedudukan di Tasikmalaya dengan produk yang dihasilkan adalah bahan-bahan Peledak khusus digunakan oleh Tentara Nasional Indonesia (TNI), baik Angkatan Darat, Laut, Udara, maupun Polisi di bawah Menteri Pertahanan Nasional.

2. Perusahaan Perseroan (Persero) PT Pindad yang didirikan berdasarkan Peraturan Pemerintah Nomor 4 Tahun 1983 berkedudukan di Bandung dengan produk yang dihasilkan adalah Produk Militer yaitu Senjata Api dan Amunisi Non Militer di bawah Menteri Pertahanan Nasional.

3. Perusahaan Perseroan (Persero) PT PAL Indonesia yang didirikan berdasarkan Peraturan Pemerintah Nomor 4 Tahun 1980 berkedudukan di Surabaya dengan produk yang dihasilkan adalah Produksi Kapal Laut khusus untuk TNI Angkatan Laut dan untuk Umum.

4. Perusahaan Perseroan (Persero) PT Industri Pesawat Terbang Nusantara yang sekarang sudah berganti menjadi PT. Dirgantara Indonesia, didirikan berdasarkan Peraturan Pemerintah Nomor 12 Tahun 1976 berkedudukan di Bandung dengan produk yang dihasilkan adalah Perakitan Pesawat Terbang di bawah Menteri Riset dan Teknologi.

Terhadap Industri Pertahanan sendiri dari sisi regulasi telah diatur dalam beberapa pengaturan sebagai landasan dalam perwujudan industri pertahanan tersebut adapun landasan tersebut antara lain dibagi menjadi empat, yaitu :

\section{a. Landasan Filosofis}

Landasan filosofis dalam industri pertahanan di Indonesia terdapat dalam pancasila yang menjadi ideologi negara Indonesia. Sila - sila dalam pancasila yang saling berkaitan satu sama lainnya untuk menjalankan industri pertahanan di Indonesia dapat dilihat sebagai berikut :

\section{Ketuhanan Yang Maha Esa}

Makna dari sila pertama ini yaitu mencakup tanggung jawab bersama dari semua golongan beragama untuk secara terus-menerus dan bersamasama meletakkan landasan spiritual, moral, dan etik yang kukuh bagi pembangunan nasional sebagai pengamalan Pancasila, dikaitkan dengan industri pertahanan sebagai industri strategis di Indonesia hal ini akan berpengaruh dalam penerapan asa profesional dalam menjalankan 
perkembangan industri pertahanan sebagaimana yang diatur dalam Pasal 2 huruf (h) Undang - Undang Nomor 16 Tahun 2012 tentang Industri Pertahanan yang menjelaskan bahwa dalam penyelenggaraan industri pertahanan dan seluruh lembaga yang berkaitan dengan Industri Pertahanan serta sumber daya yang ada di dalamnya harus dapat menjalankan fungsinya masing - masing sesuai dengan kapasitas dan kapabilitas yang mengacu pada ketentuan di dalam Undang - Undang dan tidak melanggar moral.

\section{Kemanusiaan Yang Adil dan Beradab}

Sila kedua dari Pancasila ini mengandung nilai-nilai kemanusiaan antara lain perlakuan yang adil antar sesama manusia, saling menghormati serta tidak berlaku sewenang-wenang terhadap orang lain. Hal ini berkaitan dalam rangka kerjasama BUMN dengan Swasta dalam menjalankan perkembangan industri pertahanan di Indonesia , dimana para pihak dalam hal ini harus menghormati hak dan kewajiban masing - masing supaya berjalannya industri pertahanan ini dapat dijalankan dengan baik.

\section{Persatuan Indonesia}

Sila ke - 3 dalam pancasila ini mengandung makna bersama membangun atau membina rasa persatuan dan nasionalisme dalam keberagaman/keanekaragaman Negara Kesatuan Republik Indonesia. Dalam hal ini landasan filosofis sila ke - 3, terwujud ketika dalam industri pertahanan terdapat konsep tiga pilar pelaku industri pertahanan dimana hal ini mencerminkan semua rakyat dalam segala bidang dapat digunakan sebagai para pihak yang terlibat untuk dapat mempertahankan dan mengembangkan industri pertahanan ,

\section{Kerakyatan Yang Dipimpin Oleh Khidmat Kebijaksanaan Dalam Permusyawaratan Perwakilan}

Sila ke - 4 ini dapat dilihat dalam birokrasi industri pertahanan, pembuatan kebijakan dasar dalam mengatur jalannya industri pertahanan haruslah berdasarkan suatu kebijaksanaan dan terhadinya musyaarah yang mufakat sehingga menimbulkan suatu keadilan bagi seluruh bagian yang terkait.

\section{Keadilan Sosial Bagi Seluruh Rakyat Indonesia}

Sila ke - 5 dari pancasila ini merupakan landasan filosofis dari tujuan atau fungsi adanya industri pertahanan di Indonesia yang menyangkut hajat hidup orang banyak. Terhadap penerapan dari sila ke -5 ini dapat dilihat pula dalam pasal 4 Undang - Undang Nomor 16 Tahun 2012 tentang Industri Pertahanan yang menjelaskan bahwa fungsi dari adanya industri pertahanan ini sendiri akan sangat bermanfaat bagi seluruh rakyat Indonesia tentunya akan adil sesuai dengan keahliannya., dan sila ini juga yang melandaskan 
harusnya adanya keadilan dalam pembagian tugas perusahaan BUMN dan swasta dalam menjalankan industri pertahanan ini supaya masyarakat yang bekerja di dalamnya dapat mendapat kesejahteraan yang sama secara adil

\section{b. Landasan Konstitusional}

Landasan Konstitusional mengenai Industri Pertahanan di Indonesia diatur dalam Undang - Undang Dasar Negara Republik Indonesia Tahun 1945, tepatnya pada Pembukaan Undang - Undang Dasar yang berbunyi bahwa

"a. tujuan Negara Kesatuan Republik Indonesia adalah melindungi segenap bangsa Indonesia dan seluruh tumpah darah Indonesia,memajukan kesejahteraan umum, mencerdaskan kehidupan bangsa, dan ikut melaksanakan ketertiban dunia yang berdasarkan kemerdekaan, perdamaian abadi dan keadilan sosial, yang senantiasa diwujudkan dalam kehidupan bermasyarakat, berbangsa, dan bernegara;

b. bahwa untuk melindungi segenap bangsa Indonesia dan seluruh tumpah darah Indonesia, serta untuk mempertahankan kedaulatan negara dan keutuhan wilayah Negara Kesatuan Republik Indonesia, pertahanan dan keamanan negara dilaksanakan melalui sistem pertahanan dan keamanan negara yang membutuhkan ketersediaan alat peralatan pertahanan dan keamanan serta didukung oleh kemampuan industri pertahanan dalam negeri yang mandiri untuk mencapai tujuan nasional;"

Landasan konstitusional dalam industri pertahanan terdapat pula dalam Pasal 30 ayat (5) Undang-Undang Dasar Negara Republik Indonesia Tahun 1945 yang menjelaskan bahwa :

"Susunan dan kedudukan Tentara Nasional Indonesia, Kepolisian Negara Republik Indonesia, hubungan kewenangan Tentara Nasional Indonesia dan Kepolisian Negara Republik Indonesia di dalam menjalankan tugasnya, syarat-syarat keikutsertaan warga negara dalam usaha pertahanan dan keamanan negara, serta hal-hal yang terkait dengan pertahanan dan keamanan diatur dengan undang-undang."

Serta dalam Pasal 33 ayat (2) Undang-Undang Dasar Negara Republik Indonesia Tahun 1945 yang menjelaskan : "Cabang-cabang produksi yang penting bagi negara dan yang menguasai hajat hidup orang banyak dikuasai oleh negara".

Landasan konstitusional ini mengartikan bahwa adanya industri pertahananIndonesia memang dapat dilakukan untuk membantu Indonesia dalam menjalankan pembangunan nasional, yaitu kegiatan yang memang ditujukan dalam rangka mewujudkan tujuan negara yang dicita - citakan dan tercantum dalam Undang - Undang Dasar Republik Indonesia Tahun 1945. 


\section{c. Landasan Operasional}

Landasan Operasional dalam Industri Pertahanan di Indonesia sudah diatur dalam Pembangunan Industri Pertahanan Nasional yang berdasarkan Rencana Pembangunan Jangka Menengah Nasional (RPJMN) 2015-2019, adapun berikut landasan operasional industri pertahanan dalam RPJMN sebagai berikut :

\section{SASARAN}

Sasaran yang ingin diwujudkan adalah meningkatnya kemandirian pertahanan dengan semakin terpenuhinya alutsista TNI yang didukung industri pertahanan dalam Negeri.

\section{ARAH KEBIJAKAN DAN STRATEGI}

Arah kebijakan pembangunan dalam rangka mencapai sasaran tersebut adalah:

1. Meningkatkan kontribusi Industri Pertahanan bagi penyediaan dan pemeliharaan Alutsita TNI;

2. Meningkatkan kontribusi Litbang Pertahanan dalam menciptakan prototipe alpalhan TNI;

Strategi untuk melaksanakan arah kebijakan tersebut adalah:

1. Peningkatan peran industri pertahanan dalam negeri, baik produksi Alutsista maupun pemeliharaan;

2. Peningkatan produk prototipe alpalhan.

\section{d. Landasan Hukum}

Landasan hukum pada industri pertahanan telah diatur dalam Undang - Undang Republik Indonesia Nomor 16 Tahun 2012 tentang Industri Pertahanan didalamnya terdapat kewajiban menggunakan Alat Utama Sistem Senjata (Alutsista) produksi dalam negeri,dalam UU tersebut juga didorong upaya alih teknologi dalam perkembangan senjata, serta terhadap penanaman modal untuk swasta yang digunakan untuk pertambahan modal dalam rangka perkembangan industri pertahanan juga digunakan landasan hukum Undang-Undang Nomor 25 Tahun 2007 tentang Penanaman Modal, dimana dalam undang-undang tersebut dilakukanpembatasan untuk penanaman modal hanya dapat dilakukan oleh investor dalam negeri.

\section{PENUTUP}

Keberadaan industri pertahanan seperti produk senjata menjadikan suatu hal yang 
penting dan menyangkut hajat hidup orang banyak dalam mempertahankan serta memberikan keamanan, sehingga dalam hal ini industri pertahanan dapat dikatakan menjadi suatu industri strategis yang mempengaruhi pula pembangunan nasional di Indonesia. Hal ini sejalan dengan landasan konstitusional dari adanya industri pertahanan yang berada pada pembukaan Undang - Undang Dasar Negara Republik Indonesia Tahun 1945.

Namun pada kenyataannya pembangunan industri pertahanan Indonesia sebagai industri strategis Indonesia masih belum bisa berjalan dengan baik karena kurangnya peran hukum sebagai sarana pembaharuan yang memiliki arti sebagai penyalur arah kegiatan manusia yang dikehendaki. Hukum yang beranggapan keteraturan dan ketertiban merupakan hal yang mutlak, dalam kasus ini hukum masih bersifat ad hoc atau mengatur secara tegas berjalannya pembangunan industr pertahanan Indonesia. Sehingga peran hukum dalam pembangunan industri pertahanan Indonesia ini tidak memberikan kepastian hukum yang jelas dan tentunya berdampak tidak munculnya suatu ketertiban dan keadilan dalam berjalannya pembangunan industri pertahanan Indonesia sebagai industri strategis Indonesia.

\section{DAFTAR PUSTAKA}

\section{Buku - Buku}

Departemen Pertahanan Republik Indonesia, 2008, Buku Putih Pertahanan Indonesia, Departemen Pertahanan, Jakarta.

Habibi Yusuf Sarjono, 2011, Peran Strategis Pembangunan Industri Pertahanan, Bandung, PT. Mandar Maju, 2011.

Juanda, 1997, Politik Internasional: Suatu Kerangka Analisis, Bima Cipta, Bandung.

Kementerian Pertahanan RI, 2010, Minimum Essensial Force, Komponen Utama Kemenpan RI, Jakarta.

Wiranto Arismunandar, 2000, Strategi Pengembangan Teknologi dan Industri Pertahanan dalam rangka Mewujudkan Kemandirian Pertahanan Nasional, PT. Erlangga, Jakarta.

Martin, 2007, The Economic of Offset: Defence Procurement and Countertrade (Terjemahan); Routledge, Amsterdam.

Mochtar Kusumaatmadja, 2002, Konsep-Konsep Hukum Dalam Pembangunan (Kumpulan Karya Tulis), Penerbit Alumni, Bandung.

Margono, 2012, Kebijakan Modernisasi Alutsista Tni Dihadapkan Pada Tuntutan Tugas, Yudhagama, Bandung. 
Sily Karim, 2014, Membangun Kemandirian Industri Pertahanan Indonesia, KPG, Jakarta.

Lili Rasjidi dan Ida Bagus Wiyasa Putra, 2003, Hukum Sebagai Suatu Sistem, Penerbit: CV. Mandar Maju, Bandung.

\section{Perundang - Undangan}

Undang - Undang Dasar Negara Republik Indonesia Tahun 1945

Undang - Undang Nomor 13 Tahun 2012 tentang Industri Pertahanan

Undang - Undang Nomor 3 Tahun 2016 tentang Perindustrian

Rancangan Pembangunan Jangka Menengah 2015-2019 